\title{
Model of Identification and Management of Technological Innovations in Product Development: A Case Study in the Automotive Industry
}

\author{
Cristian Lucas Endler ${ }^{1} \&$ Pedro Paulo de Andrade Júnior ${ }^{1}$ \\ ${ }^{1}$ Centro Tecnológico de Joinville, Universidade Federal de Santa Catarina, Joinville, Brazil \\ Correspondence: Pedro Paulo de Andrade Júnior, R. Dona Francisca, 8300 - Bloco U. Zona Industrial Norte. \\ Joinville, SC. Brazil. Tel: 55-047-984-560-962. E-mail: cristianendler06@hotmail.com
}

Received: September 10, 2018

Accepted: October 9, 2018 Online Published: October 11, 2018

doi:10.5539/emr.v7n2p30

URL: http://doi.org/10.5539/emr.v7n2p30

\begin{abstract}
This article aims to propose a new model of technological innovations, as well as using it in a case study in the automotive industry. After an analysis of the main scientific databases, it was verified that the present work is unprecedented in presenting a unified model of identification and management of technological innovations. In methodological terms, the bibliometric and systemic analyzes were performed in order to identify the main technological innovations inherent in the automotive industry. In terms of research results, a cohesive innovation model was obtained, which, once based on the concepts of sensitive innovation and latent innovation, allows the identification and the consequent valuation of the economic potential of the main technological innovations in the area desired by the manager who will apply it. As an example, the model was applied specifically in the automotive sector, but its methodology can be generalized to any area of industrial production.
\end{abstract}

Keywords: technological innovation, product development, automotive industry

\section{Introduction}

In recent years, the global market is constantly under pressure for innovation in order to meet or exceed consumer expectations. At the same time, the aim is to reduce production costs, which is essential for the survival and prosperity of industrial organizations in a competitive market (Júnior, Ensslin, \& Ensslin, 2011).

Despite the tendency of the organizations to polarize their innovation efforts on the product itself, due to the fact that these are more noticeable to the final consumer, the innovation in product development processes can also generate numerous benefits to the organizations, such as the aforementioned cost reduction, delivery lead-time reduction, product quality improvement, increased flexibility and other business objectives (Davenport, 2013).

One of the industry sectors that present high rates of technological innovation is the automotive sector.In this sense, the automotive industry in general has shown an exponential growth in research and development processes (R\&D), which represented a turning point in the way in which automakers and suppliers manage their innovation (GURZ et al., 2017). For the success of this management, it is extremely necessary to use a cohesive model for the analysis of technological innovation, especially in extremely competitive sectors, such as the aforementioned automotive sector.

The studies inherent in the establishment of technological innovation models are nonexistent and its use becomes more important every day in competitive sectors such as the automotive one. In light of this scenario, the following problem arises: how to develop a model of identification and management of technological innovation for the industry and how is it applied in a case study in the automotive industry??

\section{Method}

\subsection{Technological Innovations in the Automotive Industry}

Nowadays, the concept of autonomous vehicles promises to revolutionize the way that cars are produced and how routes and cities are planned. The implementation of this innovation can make the human factor no longer relevant in the vehicle safety. Despite this considerable advantage over non-autonomous vehicles, the introduction of such a radical innovation is fraught with uncertainties. 
It is in the direction of analysis of market uncertainties that the work of Konig and Neumayr (2015) stands out, that is, the authors analyze the resistance of the users to the introduction of the autonomous driving. In this study, the conclusion is that, in general, people are reluctant to cede control of their vehicles to technology, and the determining factor for this refusing is the possibility of system's malfunction, which could lead to serious collisions. However, it is shown that younger people and those that own vehicles with a higher level of automation are less resistant to this new technology.

The authors Gurz et al. (2017) perform a classification of hydrogen-powered vehicles, detailing the characteristics of electric vehicles provided with hydrogen fuel cells and describing their advantages, both operationally and economically. Amongst the advantages of fuel cell-powered electric vehicles, it is possible to cite higher energy conversion efficiency, fast adaptability to sudden changes in the road loads, longer autonomy and zero emissions.

Zapata and Nieuwenhuis (2009) analyze both incremental and radical innovations in the automotive industry, focusing on the area of emission mitigation. The implementation of product innovations in the automotive industry only occurs through intensive cost amortization analysis, that is, design alternatives that require the creation of new production processes or that require the abandonment of existing processes are difficult to put in practice.

Incremental innovations are more likely to be accepted by the automotive industry. Among these incremental innovations, it can be mentioned the use of biofuels and the production of hybrid vehicles, that use internal combustion engines combined with electric motors (Zapata \& Nieuwenhuis, 2009).

Among the radical innovations in the area, Zapata and Nieuwenhuis (2009) cite the fuel cell vehicles, which have the main obstacles the cost and complexity of creating a hydrogen supply infrastructure.

In contrast to the above, Pohl and Yarime (2012) consider the electrification of the automotive fleet as a radical innovation, based on the fact that internal combustion engines were the basis of the automotive industry throughout the twentieth century.

Lee and Berente (2013) consider that the sub-area of pollution mitigations passes through an "era of incremental innovation" that, conceptually, is the period of stability that occurs after a radical innovation, this period began after the introduction of the catalytic converters in the automotive industry in the late 1970s. During the period of incremental innovation, the product architecture remains the same and the company shifts its attention to innovation associated with the manufacturing, cost analysis, market analysis and component enhancements.

In the work of Beaume, Maniak and Midler (2008), it is noticeable that in the current automotive industry, product renewal is more frequent than the addition of radical innovations. The phenomenon is explained by the concentration of innovation in suppliers of subsystems for the automotive industry, which causes only incremental innovation in the final product.

The study of Mondéjar-Jimenéz et al. (2013) deals with competitive advantages acquired by companies in the automotive sector that uses eco-design or environmental-based design (EBD), which consists, among other practices, in the use of renewable materials, in the reducing of the emission levels of the vehicle and the reducing of the energy consumed during the manufacturing process.

The work of Lu, Broughton and Winfield (2014) deals with the innovation in dismantling techniques for the repair and recycling of automotive vehicles. The authors identify the current challenge related to the union of dissimilar materials in structural applications, such as in automotive chassis. The economic and technical viability are identified so that conventional union methods, such as welding and riveting, will be completely replaced by adhesive bonding processes.

The advantages of adhesive bonding are the possibility of permanent union between dissimilar materials, uniform distribution of joint stress and weight relief ( $\mathrm{Lu}$ et al., 2014).

The study of Mayyas et al. (2012) analyzes the relationship between the life cycle of automotive products and their environmental impact. The authors describe ways in which application of "design for X" methodologies during the development of automotive products can make this relationship less conflicting. And come to the conclusion that the application of such design mechanisms is substantial for market success of the automotive product, whereas the demand for sustainable products grows exponentially every year.

Sarasini (2014) analyzes the research and development (R\&D) competencies that the organization must develop in case of a possible electrification of the car fleet, since the technical skills necessary for the design of electric vehicles and vehicles with combustion engines are different. The author concludes that manufacturers should intensify research collaboration with academic institutions, given the interdisciplinary bias of electric vehicle design. 
From the above, it can be seen that the increase in search for environmental sustainability has been the preponderant factor in the promotion of innovation in the automotive industry. Nevertheless, it must be reiterated that such innovations will find practical applications only if they are economically viable.

In this context of economic criticality of the automotive industry, it is necessary to apply cohesive methodologies of product development, since this stage is decisive for the economic viability of industrial products, especially in an industry as competitive as the automotive one.

\subsection{Product Development in the Automotive Industry}

A contemporary trend for product development in the automotive industry is the concept of "design for customization". This methodological bias aims at satisfying the consumer's requirements, increasing the variety of customization of the product, without corresponding to a vertiginous increase in costs and delivery lead-time (Tseng \& Jiao, 1996).

According to the authors Tseng e Jiao (1996), the costs of implementing the design for customizations are easily amortized in the case of production of vehicle in large scale. In the production of out-of series or small-scale vehicles, it is necessary to pass these costs to the final consumer, which is plausible, since such consumers are likely to pay more for exclusive products. This relationship between the amortization of the cost of the method and the production volume required is shown in figure 1.

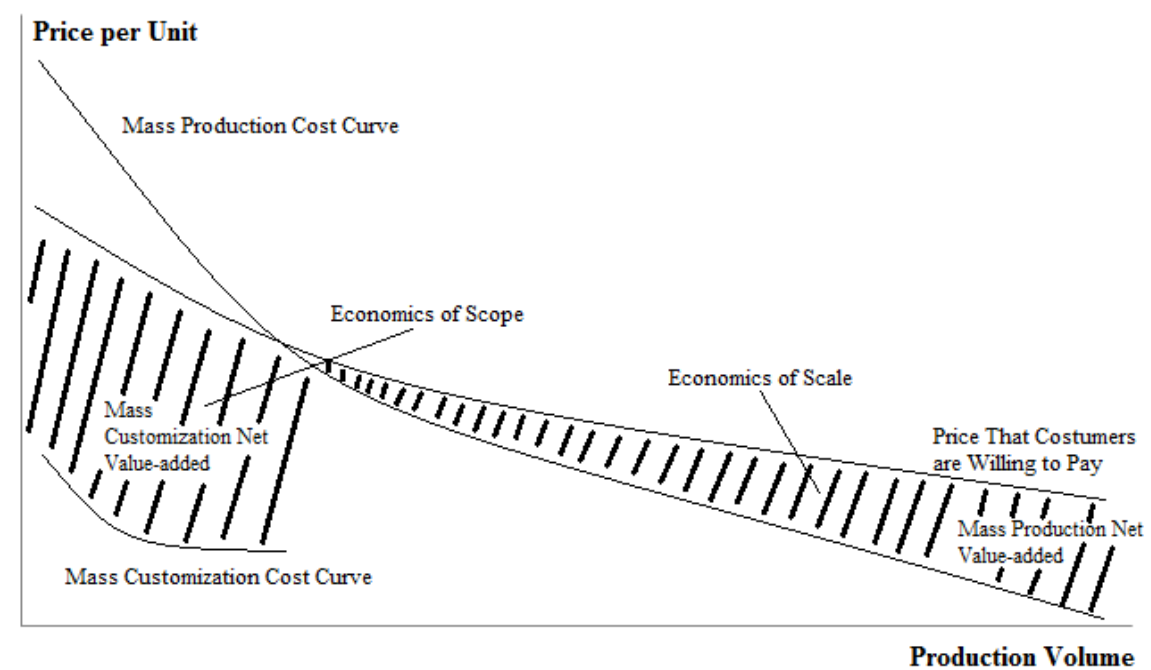

Figure 1. Amortization of the cost of implementing the design for customization concept in function of the production volume (Tseng \& Jiao, 1996)

Due to the vertiginous competitiveness in the automotive industry, the development of scenarios should be an integral part of the product development process, that is, it is necessary to anticipate the study of new technologies and the analysis of the future economic trend in the industrial sector (Arcos-Novillo \& Güemes-Castorena, 2017). The study of Liu, Liu and Chen (2014) aim to scenario development from the environmental goals to be met in the future. The authors polarize their efforts in the Chinese automotive industry and conclude that for future pollutant mitigation standards to be met, large investments will be required in research of new materials and new manufacturing processes.

Aiming at cost reduction in the preliminary design phase, the rapid prototyping technique has been used extensively in the automotive industry. The use of rapid prototypes for flow tests and for the analysis of possible product design can culminate into vertiginous cost reduction during the development of the product, due to the fact of allowing quick identification of design errors, with the advantage of avoiding the costly making of polymer injection molds (Elverum \& Welo, 2015).

In resume, the latest trends in product development in the automotive industry are mainly focused on adapting products to consumers and environmental requirements.

\subsection{Bibliometric Analysis}

Bibliometric analysis is the statistical approach of bibliographic data, which focuses on the analysis if the quantity 
of citations of a given set of publications. Through the bibliometric analysis, it is possible to raise the state of art of a certain area of knowledge, aiming at the identification of research opportunities.

The database chosen for the present study was the Scopus, belonging to the Elsevier group. The keyword combinations used are listed at Chart 1 . In order to delimit the outputs of the research to articles strictly inherent to the present theme, different keywords were combined through the Boolean operator "AND".

\begin{tabular}{|c|}
\hline Keyword combinations \\
\hline Technologic* AND Innovation \\
\hline Product AND Development \\
\hline (Technologic* Innovation) AND (Automotive Industry) \\
\hline (Product Development) AND (Automotive Industry) \\
\hline Innovation AND Methodology \\
\hline
\end{tabular}

Chart 1. Keyword combinations used in the search engine of the Scopus database

The areas of greatest inheritance to the topic of the present work present in Scimago Journal Rank are listed in Chart 2. The delimitation of such areas constituted a search filter to the selection of articles portfolio.

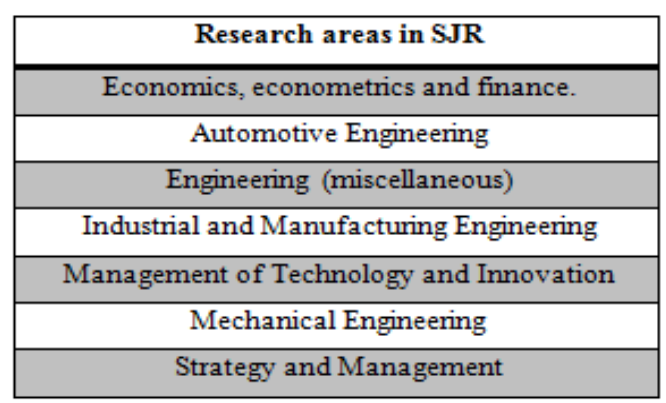

Chart 2. Research areas in SJR inherent to the present work

The journals of the areas cited in Chart 2 were sorted in descending order of SJR index. Due to the fact that the present work only aims to higher impact factor journals, only the first quartile of that list was selected.

First, the keyword combinations present in the Chart 1 were applied to the search engine of the Scopus database, considering the fields "article title", "abstract" and "keywords". It was observed that this search returned an excessively large set of articles, which, in practice, makes it impossible to read all the articles found.

In view of this fact, the database search fields were limited to the title of the articles. This choice limited the returned number of articles to a reasonable reading value. In addition, the limitation of keywords to the title returned articles more strict inherent to the subject of this work. Table 1 shows the number of articles returned by Scopus based in the combination of keywords used and the type of search field limitation. 
Table 1. Number of articles returned by Scopus database according to the filtering criteria used

\begin{tabular}{ccc}
\hline Keyword combinations & $\begin{array}{c}\text { Number of articles returned with } \\
\text { the search in "All Fields" }\end{array}$ & $\begin{array}{c}\text { Number of articles returned } \\
\text { with the search in "article title" } \\
\text { field }\end{array}$ \\
\hline $\begin{array}{c}\text { Technologic* AND Innovation } \\
\text { Product AND Innovation } \\
\text { (Technologic* Innovation) AND } \\
\text { (Automotive Industry) }\end{array}$ & 35974 & 3429 \\
(Product Development) AND \\
(Automotive industry) \\
Innovation AND Methodology
\end{tabular}

After reading some articles returned from the combinations of keywords (Technologic* AND Innovation) and (Product AND Innovation), it was verified that these combinations result in articles very dispersed to the subject of the present study. From this fact, a greater attention was paid to the articles provided by the search with the other three keyword combinations.

After applying the other selection criteria mentioned above, a list of journals sorted in descending order of the SJR index was reached. However, for simplicity, it was preferred to show here only the periodicals that are widely used in the systemic analysis. Table 2 illustrates this set of journals.

Table 2. Journals used in the present work

\begin{tabular}{cc}
\hline Journal & SJR index \\
\hline Research Policy & 3.625 \\
Renewable and Sustenable Energy Reviews & 3.051 \\
International Journal of Production Economics & 2.261 \\
Journal Of Cleaner Production & 1.616 \\
Environmental Innovation and Societal Change & 1.261 \\
Technological Forecasting and Social Change & 1.247 \\
Adhesion and Adhesives & 0.904 \\
Applied Ergonomics & 0.875 \\
Futures & 0.825 \\
\hline
\end{tabular}

In addition to the bibliometric analysis, it is necessary to do a more qualitative and detailed analysis of the articles sample set. This approach is called systemic analysis, which will be detailed in the next section.2.3.1 Sample Size, Power, and Precision

Along with the description of subjects, give the mended size of the sample and number of individuals meant to be in each condition if separate conditions were used. State whether the achieved sample differed in known ways from the target population. Conclusions and interpretations should not go beyond what the sample would warrant.

\subsection{Systemic Analysis}

The systemic analysis consists in the evaluation of a sample set of article on a given research topic, aiming to find the bases and knowledge deficits in the analyzed sample.

In order to perform the systemic analysis in the present study, a chart of presentation and analysis of systemic results was used. By mapping the systemic variables of the present study, it is possible to identify the current technological innovations being employed in the automotive industry in the column of research results of the articles, as well as it is possible to make a projection of the future innovation in the area, in the columns of future recommendations and in the authors' research gaps. 
From the systemic analysis of the theoretical reference, it was possible to reach the thematic axes listed in Chart 3. The material contained in Chart 3 constitutes the raw material used for the subsequent identification of the man innovations in the automotive industry and for the consequent valuation thereof.

\section{Variable}

Addressed by the authors
Results about the variable Future recommendations
about the variable
Limitations and research gaps about the variable

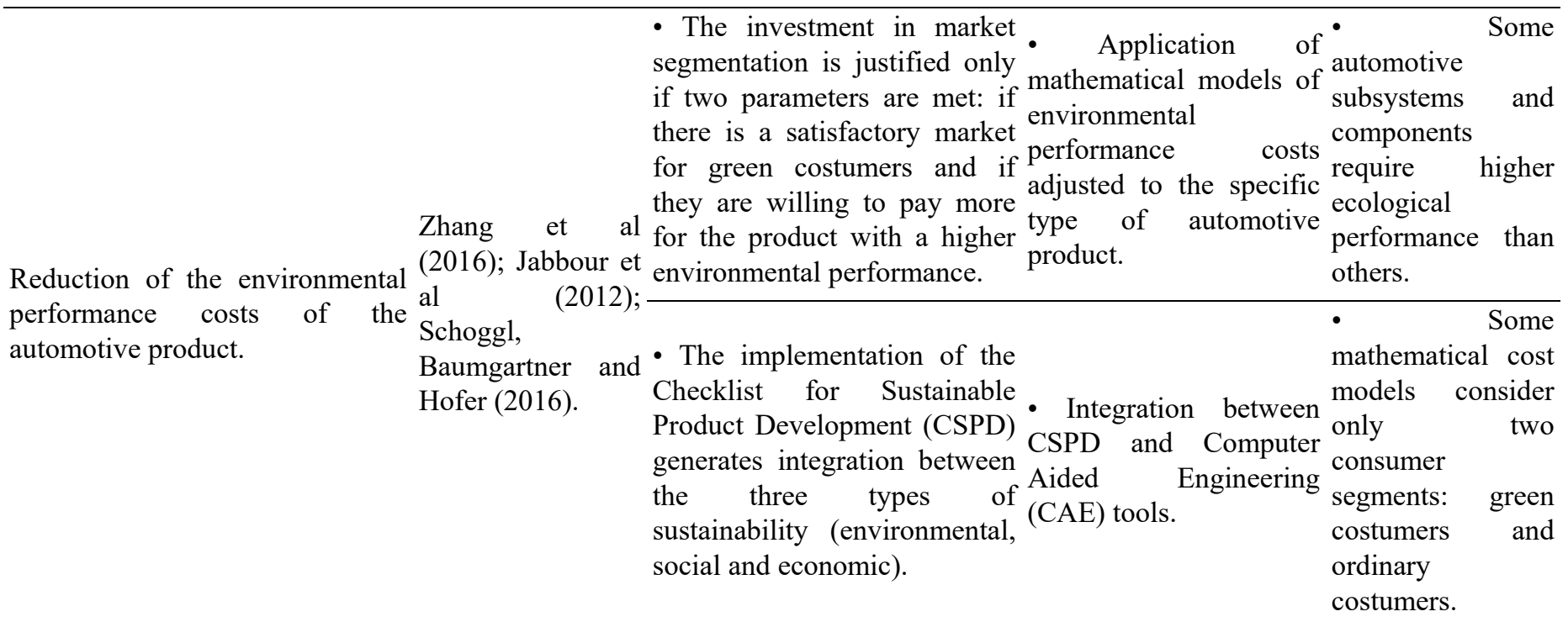

Rauch, Dallasega
Lean It is proven that the use of $\begin{aligned} & \text { Investigate the } \\ & \text { (LPD). }\end{aligned}$

\begin{aligned} & \hline The application of the \\ & concept of Design for \\ & Customization \end{aligned}

Design for Customization.

Persson (2016); achieving a wider range of

Tseng e Jiao customers without the high (2011); cost of developing a new Elgammalet al product.

(2017)
- The key steps for design success for customization are the conceptual design and the preliminary design.
- Investigation of a mechanism that allows the complete knowledge of the needs of the customers before the launch of the automotive product.

- Comparison between real and virtual prototyping

- Application of rapid additive manufacturing for structural components.

- Decrease of time of the additive manufacturing. 
product.

- Through the use of virtual reality it is possible to inspect the design of the car without the need to build a physical prototype.

Use of virtual reality in the Lawson, Salanitri development of automotive e products (2015)
Waterfield - Virtual reality can be effective in the training of assembly line employees.
- Today, virtual reality is far from providing a real immersion experience.

- It is necessary to reduce costs of virtual reality devices to make this concept competitive against real prototyping.

- The use of virtual reality reduces the lead-time of product development.

- Parallel to the use of vehicle with fuel cells, the electrification of the car fleet

Pohl e Yarime is certain

Electificationofautomotivevehicle (2012); Sarasini (2014)

- Hybrid vehicles have greater economic viability in a short period of time.
- Development of batteries with higher energy capacity. (a)
- Generation of
clean energy to meet the demand of electric vehicles.
- The complexity and the high

Modularization Cabigiosu, Zirpoli cost of developing cars can be e Camuffo (2012). mitigated through the modularization of the product.
- Industry configurations - Quantification of and specificities that suppliers of influence the role of components and modularity in the subsystems to the integration of external concept of sources of innovation. modularization.
- All classes of materials can be joined by adhesive bonding techniques, including dissimilar materials.
Application of adhesive bonding techniques in automotive subsystems.
Lu, Broughton e Winfield (2014).
- Adhesive bonding generates less stress concentration than other bonding methods, such as welding and riveting.

- This type of joint prevents interface oxidation between materials.
- Difficulty in disassembling adhesive joints.

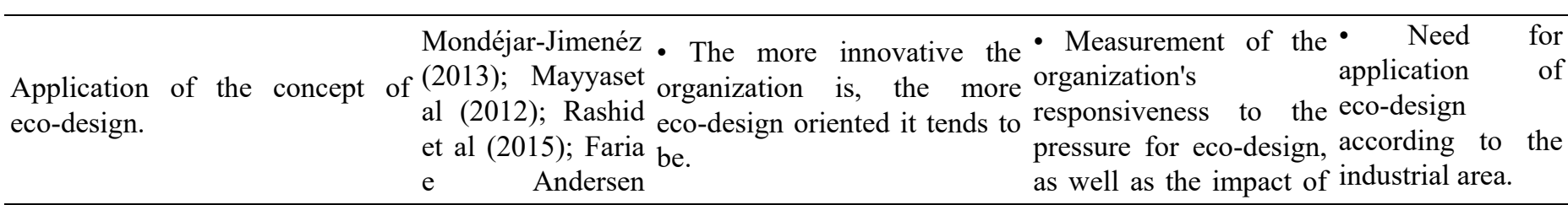


(2016); Liu, Liu e Chen (2014)
- Through the application of eco-design, organizations greatly increase Market-share. their ir specifically

- With regard to eco-design, organizations can be classified into three types: eco-balanced, eco-marketers (use eco-design as a ruse to conquer new markets) and eco-blind (that deny the need for environmental performance).

- Eco-design is a great cost-effective alternative for organizations, due to the increasing cost of automotive raw materials.

- The automotive industry suffers the most pressure for eco-design across the industrial spectrum. eco-innovation for a $\cdot$ Limiting the sustainable performance identification of pecifically on green green innovations with patent visualization only.

\section{Chart 3.Composition of the thematic axis of the present study}

\section{Technological Innovation Model in Product Development in the Automotive Industry}

The main objective of the present study is to propose a new technological innovation model in product development and apply it in the automotive industry. After an analysis of the theoretical framework intrinsic to the innovation and of the proposed methods of bibliometric and systemic analysis, we arrived at a concise model, based in two axes, which make up the structure of the same. The axes of this innovation model are listed below:

1) Identification of product development innovations in the desired industrial sector;

2) Qualitative assessment of the innovations found;

The first axis of the proposed model is obtained from the application of bibliometric analysis and systemic analysis, described in the previously sections.

Through bibliometric analysis, we obtain the gross sample set of articles inherent to innovations in products in the desired industrial sector. From the systemic analysis, the innovations are identified. In this work, it was decided to divide the innovations identified in two groups, shown in Chart 4.

\begin{tabular}{|c|c|}
\hline $\begin{array}{l}\text { Groups of proposed } \\
\text { innovations }\end{array}$ & Description of the group of innovations \\
\hline Sensible innovation & $\begin{array}{c}\text { These are the technological innovations already applied commercially in the } \\
\text { desired industrial sector }\end{array}$ \\
\hline Latent innovation & $\begin{array}{c}\text { Are the technological innovations still in research / prototyping phase in the } \\
\text { desired industrial sector }\end{array}$ \\
\hline
\end{tabular}

Chart 4. Groups of innovations proposed in the present study

The sensible innovations are identified in the "main results" column of chart 3 , in the appendix A. Latent innovations are identified in the columns of "future recommendations" and "research gaps" in chart 3.

It is substantial for managers of the companies and suppliers to polarize human and financial efforts only on innovations that could result in profits for the organization. 
In this sense, it is proposed as the second and last axis of the proposed model the qualitative evaluation of the innovations found in the first axis. The proposed criteria for such valuation are distinct for sensitive innovations and latent innovations and are shown in chart 5.

\begin{tabular}{|c|c|}
\hline $\begin{array}{c}\text { Valuation criterion for } \\
\text { sensible innovation }\end{array}$ & $\begin{array}{c}\text { Number of articles of the last ten years, present in the Scopus database, that } \\
\text { directly address the sensitive innovation in question. }\end{array}$ \\
\hline $\begin{array}{c}\text { Valuation criterion for } \\
\text { latent innovation }\end{array}$ & $\begin{array}{c}\text { Number of articles from the last five years, present in the Scopus database, } \\
\text { that directly address the latent innovation in question. }\end{array}$ \\
\hline
\end{tabular}

Chart 5.Valuation criteria proposed for sensible innovation and latent innovation

The higher the innovation valuation index, that is, the greater is the number of articles that approach it directly, the greater is the probability of applying it to the industrial level. This probability is demonstrated from the level of effort demanded by the researchers to study these innovations.

In sum, through the application of this new model of analysis of product innovation, it is possible to identify current innovations that are applied in a certain area of the industry, as well as to identify innovations that will be part of the market in a near future. In addition to exposure, the present model allows an estimation of the economic relevance of the innovations found in the systemic analysis process.

Applying the proposed methodology to the automotive sector, as a case study and using the results of the systemic analysis presented in Chart 3 , it is possible to identify which are the sensitive and latent innovations in product development in the current automotive industry.

By applying the aforementioned criteria, it can be seen that the most important sensitive innovations in the current automotive industry are those listed in Chart 6 , in descending order of relevance.

\begin{tabular}{|l|}
\hline Order of relevance of the sensible innovations found \\
\hline 1) Application of the concept of eco-design in the development of automotive \\
products \\
\hline 2) Rapid prototyping application coupled with the Scrum concept \\
\hline 3) Application of the concept of Design for Customization \\
\hline 4) Segmentation of market aiming at the environmental performance of the \\
automotive product \\
\hline 5) Application of the CSDP (Checklist for Sustainable Product Development) \\
\hline products
\end{tabular}

Chart 6.Order of relevance of the sensible innovations found in the systemic analysis

From the view of Chart 6 , it can be seen that the concept of greater applicability in the current automotive industry is inherent to the application of eco-design, due to the fact that automakers and suppliers of subsystems and automotive components are under increasing pressure for the generation of less environmental impact.

The latent innovations are those that are still in the research phase and that will certainly find practical application in the industry in a near future. Analyzing the columns of "future recommendations on the variable" and "research gaps on the variable", it is possible to identify such latent innovations, which are sorted in descending order of relevance in Chart 7. 


\begin{tabular}{|l|}
\hline Order of relevance of the latent innovations found \\
\hline 1) Application of mathematical models of environmental performance cost adjusted to the \\
specific type of automotive product
\end{tabular}

Chart 7.Order of relevance of the latent innovations found in the systemic analysis

From Chart 7, it can be seen that the mathematical modeling of eco-design costs will consist of a substantial stage of product development in the automotive industry in a near future. It is also noticeable the increasing use of computational means in the process of developing automotive products, which can be explained by the fact that we are experiencing the fourth industrial revolution (the advent of "industry 4.0").

The Figure 2 summarizes, as an illustrative flowchart, the technological innovation model developed in the present study, applied in a case study in the automotive industry. 


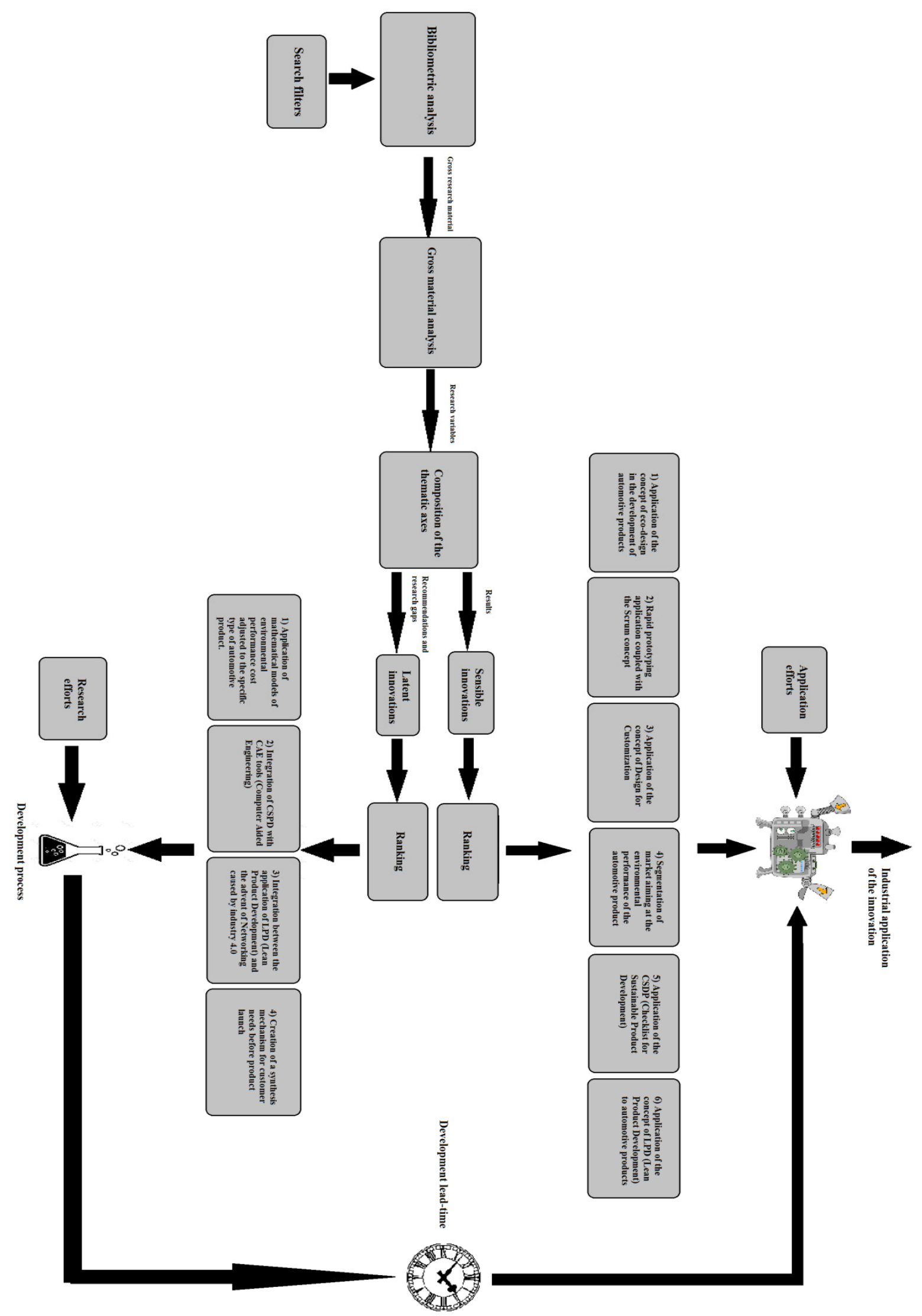

Figure 2. Model of technological innovation developed in the present study 


\section{Discussion}

In the present study, the proposal of a new model of identification and managementof technological innovation in product development was carried out.A case study in the automotive industry was conducted in order to demonstrate more intuitively the application of the created model.The innovations in this area could be classified unprecedently in sensitive innovations and latent innovations. The concept of sensitive innovation allows identifying the technological innovations already applied in the desired industry, since the notion of latent innovation allows the contemplation of the technological innovations with possibility of application in the intended industrial sector in a near future.

In the light of the research results, it became apparent that the automotive industry is under severe pressure for the application of eco-design concepts in their products. In this sense, most technological innovations in the automotive industry will be polarized in this area in the coming years. It is in this same sense that the concept application of CSPD appears prominently in such area.

The advent of industry 4.0 means that most of the innovations identified are related to the integration between management and computational tools. The rise of competition in all subsectors of the automotive industry creates a greater need for attention to customer requirements, which justifies the appearance of design for customization and the creation of mechanisms to synthesize customer needs among the main innovations in this industry.

The contribution of this article is centered on the fact that the analysis and prospection of technological innovation opportunities need systematization in order to achieve full efficiency. In light of this scenario, the present work fulfilled the function of presenting a concise model of technological innovation, andit's application being exemplified from a case study in the automotive industry, although the methodology can be generalized and applied to any area of the industrial production

\section{References}

Arcos-Novillo, D. A., \& Güemes-Castorena, D. (2017). Development of an additive manufacturing technology scenario for opportunity identification - The case of Mexico. Futures, 90, 1-15. https://doi.org/10.1016/j.futures.2017.05.001

Beaume, R., Maniak, R., \& Midler, C. (2008). Crossing innovation and product projects management: A comparative analysis in the automotive industry. International Journal Of Project Management, 27(2), 166-174. https://doi.org/10.1016/j.ijproman.2008.09.004

Cabigiosu, A., Zirpoli, F., \& Camuffo, A. (2012). Modularity, interfaces definition and the integration of external sources of innovation in the automotive industry. Research Policy, 42(3), 662-675. https://doi.org/10.1016/j.respol.2012.09.002

Davenport, T. H. (2013). Process innovation: Reengineering work through information technology. Cambridge: Harvard Business Press.

Elgammal, A. (2017). Design for Customization: A New Paradigm for Product-Service System Development. Procedia Engineering, 64, 345-350.

Elverum, C. W., \& Welo, T. (2015). On the use of directional and incremental prototyping in the development of high novelty products: Two case studies in the automotive industry. Journal Of Engineering And Technology Management, 38, 71-88. https://doi.org/10.1016/j.jengtecman.2015.09.003

Faria, L. G. D., \& Andersen, M. M. (2016). Sectoral patterns versus firm-level heterogeneity - The dynamics of eco-innovation strategies in the automotive sector. Technological Forecasting \& Social Change, 117, 266-281. https://doi.org/10.1016/j.techfore.2016.11.018

Gartzen, T., Brambring, F., \& Basse, F. (2016). Target-oriented prototyping in highly iterative product development. Procedia Engineering, 51, 19-23.

Gurz, M. (2017). The meeting of hydrogen and automotive: A review. International Journal of Hydrogen Energy, 42(36), 1-13. https://doi.org/10.1016/j.ijhydene.2017.02.124

Jabbour, C. J. C. (2012). Environmental management and operational performance in automotive companies in Brazil: the role of human resource management and lean manufacturing. Journal of Cleaner Production, 47, 129-140. https://doi.org/10.1016/j.jclepro.2012.07.010

Junior, E. D. B., Ensslin, L., \& Ensslin, S. R. (2011). Supply chain performance evaluation: A case study in a company of equipment for refrigeration. In Technology Management Conference (ITMC), 2011 IEEE 
International (pp. 969-978).

Konig, M., \& Neumayr, L. (2015). Users' resistance towards radical innovations: The case of the self-driving car. Transportation Research, 44, 42-52.

Lawson, G., Salanitri, D., \& Waterfield, B. (2015). Future directions for the development of virtual reality within an automotive manufacturer. Applied Ergonomics, 53(B), 323-330.

Lee, J., \& Berente, N. (2013). The era of incremental change in the technology innovation life cycle: An analysis of the automotive emission control industry. Research Policy, 44(8), 1469-1491. https://doi.org/10.1016/j.respol.2013.05.004

Liu, Y., Liu, Y., \& Chen, J. (2014). The impact of the Chinese automotive industry: scenarios based on the national environmental goals. Journal of Cleaner Production, 96, 102-109. https://doi.org/10.1016/j.jclepro.2014.05.015

Lu, Y., Broughton, J., \& Winfield, P. (2014). A review of innovations in disbonding techniques for repair and recycling of automotive vehicles. Adhesion and Adhesives, 50, 119-127. https://doi.org/10.1016/j.ijadhadh.2014.01.021

Mayyas, A. (2012). Design for sustainability in automotive industry: A comprehensive review. Renewable and Sustainable Energy Reviews, 16(4), 1845-1862. https://doi.org/10.1016/j.rser.2012.01.012

Mondéjar-Jimenéz, J. (2013). Segmentation of the Spanish automotive industry with respect to the environmental orientation of firms: towards an ad-hoc vertical policy to promote eco-innovation. Journal of Cleaner Production, 86, 238-244. https://doi.org/10.1016/j.jclepro.2014.08.034

Persson, J. G. (2016). Current Trends is Product Development. Procedia Engineering, 50, 378-383.

Pohl, H., \& Yarime, M. (2012). Integrating innovation system and management concepts: The development of electric and hybrid electric vehicles in Japan. Technological Forecasting \& Social Change, 79(8), 1431-1443. https://doi.org/10.1016/j.techfore.2012.04.012

Rashid, N. (2015). State of the Art of Sustainable Development: An Empirical Evidence from Firm's Resource and Capabilities of Malaysian Automotive Industry. Procedia Social and Behavioral Sciences, 195, 463-472. https://doi.org/10.1016/j.sbspro.2015.06.488

Rauch, E., Dallasega, P., \& Matt, D. T. (2016). The way from Lean Product Development (LPD) to Smart Product Development (SPD). Procedia Engineering, 50, 26-31.

Ringen, G., \& Welo, T (2016). Learning and knowledge systems in product development environments. Procedia Engineering, 57, 49-54.

Sarasini, S. (2014). Electrifying the automotive industry: The geography and governance of R\&D collaboration. Environmental Innovation and Societal Transitions, 13, 109-128. https://doi.org/10.1016/j.eist.2014.05.001

Schoggl, J. P., Baumgartner, R. J., \& Hofer, D. (2016). Improving sustainability performance in early phases of product design: A checklist for sustainable product development tested in the automotive industry. Journal of Cleaner Production, 140(3), 1602-1617.

Tseng, M. M., \&Jiao, J. (1996). Design for Mass Customization. Procedia Engineering, 45(1), 111-115.

Zapata, C., \& Nieuwenhuis, P. (). Exploring innovation in the automotive industry: new technologies for cleaner cars. Journal of Cleaner Production, 18(1), 14-20. https://doi.org/10.1016/j.jclepro.2009.09.009

Zhang, Y. (2016). The impact of development cost on product line design and its environmental performance. Int. J. Production Economics, 184, 122-130. https://doi.org/10.1016/j.ijpe.2016.10.027

\section{Copyrights}

Copyright for this article is retained by the author(s), with first publication rights granted to the journal.

This is an open-access article distributed under the terms and conditions of the Creative Commons Attribution license (http://creativecommons.org/licenses/by/4.0/). 